\title{
塗り床の耐動荷重性とコンクリート床下地の表層部品質の関係 RELATIONSHIP BETWEEN DURABILITY AGAINST DYNAMIC LOAD OF RESIN FLOOR COATING AND SURFACE LAYER QUALITY OF SLAB CONCRETE
}

\author{
藤井 佑太朗*1, 高 山博 樹*2, 福田 眞太郎*3, 横 山 裕 ${ }^{* 4}$ \\ Yutaro FUJII, Hiroki TAKAYAMA, Shintaro FUKUDA \\ and Yutaka YOKOYAMA
}

\begin{abstract}
Resin floor coating is used for such as logistics facilities. However, those floors could be subjected to great complicated load. Due to the load, the cases are reported that the problems with the floors occur. Durability against dynamic load of resin floor coating is strongly affected by surface layer quality. In this study, the relationship between durability against dynamic load of resin floor coating and surface layer quality is considered. As a result, it is proved that preparation of slab by the way shown in this study and securement of appropriate layer intensity could decrease the possibility of primary problems.
\end{abstract}

Keywords: Resin floor coatings, Durability against dynamic load, Slab concrete, Surface layer quality, Surface strength, Peeling 塗り床, 而動荷重性, コンクリート床下地, 表層部品質, 表面強度, 剥離

\section{1. はじめに}

コンクリート床下地上に高分子系の塗り床材を塗って仕上げる “塗り床”は、一般に機械的特性に優れていることから、大きな機 械的負荷がかかる物流施設や生産施設などの床に広く普及してい る。これらの施設の床には、搬送車など、床上の機器の動作による 動荷重が頻繁に作用する。これらの動荷重の大きさ，性状は、機器 の重量化および高機能化にともない、より増大かつ複雑化する傾向 にある。また、機器の自動化にともない、同じ場所で繰り返し作用 することも、特徴として挙げられる。したがって、これらの機器が 使用される床では、想定される動荷重に対し十分な耐久性を有する 塗り床材を選定する必要があるが、塗り床の耐久性には床下地の表 層部品質が影響する ${ }^{1)}$ た、所期の性能を発揮するためには、施工 時における床下地の表層部品質の確保も重要となる。特に、剥離な どの不具合が供用開始後すぐに発生した場合、明らかな施工上の問 題と捉えられ、クレームなどにつながることが容易に予想される。 しかし、塗り床の動荷重に対する耐久性（以降“耐動荷重性”之記 す)と床下地の表層部品質の関係を検討した例は少なく、不具合発 生を未然に防ぐための基礎的な知見が不足している。

本報は、搬送車などのキャスターによる動荷重を対象に、塗り床
の耐動荷重性と塗り床材施工時の床下地の表層部品質の関係につい て、施工方法を種々変化させて作製した床下地を用いて実験的に検 討した経過，結果を述べるものである。

\section{2. 目的, 範囲}

本研究は、物流施設や生産施設などの床に一般的に用いられてい る塗り床を対象に、繰り返し作用する動荷重により供用開始後比較 的早い段階で発生する不具合と床下地の表層部品質の関係を把握 し、初期不具合防止の観点から床下地に要求される表層部品質を、 それを具現するための施工方法とともに提示することを目的とす る。

本研究で対象とする動荷重は、物流施設や生産施設などの床に作 用する代表的な動荷重の1つであり、かつ塗り床にとって過酷と思 われる、搬送車などのキャスターが曲折する際の動荷重とする。ま た、床下地の施工方法については、コンクリート打ち込み後の上面 仕上げ作業およびその後の養生の方法に加え、塗り床材の施工前に 表面の脆弱層の除去や目荒らしなどの目的でしばしば行われるポ リッシャ掛けの影響についても検討する。

\footnotetext{
*1 東京工業大学環境 $\cdot$ 社会理工学院建築学系 研究員 $\cdot$ 博士 (工学)

*2 当時、東京工業大学環境 · 社会理工学院建築学系 修士 (工学)

*3 東京工業大学環境 $\cdot$ 社会理工学院建築学系 助教 $\cdot$ 博士 (工学)

*4 東京工業大学環境・社会理工学院建築学系 教授・工博
}

Researcher, Dept. of Architecture and Building Eng., School of Environment and Society, Tokyo Institute of Technology, Dr.Eng.

Dept. of Architecture and Building Eng., School of Environment and Society, Tokyo Institute of Technology, M.Eng.

Assist. Prof., Dept. of Architecture and Building Eng., School of Environment and Society, Tokyo Institute of Technology, Dr.Eng.

Prof., Dept. of Architecture and Building Eng., School of Environment and Society, Tokyo Institute of Technology, Dr.Eng. 


\section{3. 既往の研究}

塗り床の耐動荷重性と床下地の諸品質との関係を検討した研究例 として、三上，坂井ら 2),3)および横山ら ${ }^{4)}$ が挙げられる。

三上，坂井らは、独自に開発したキャスター走行式載荷装置を用 い、塗り床の剥離の発生しにくさの程度、寸なわち耐剥離性と、床 下地に用いたモルタルもしくはコンクリートの圧縮強度 $(\phi 5 \times 10 \mathrm{~cm}$ もしくは $\phi 10 \times 20 \mathrm{~cm}$ の円柱供試体にて測定)、床下地の表面強度 (5. 2で述べる引っかき試験器にて測定), 表面粗さ、および塗り床材施 工後の接着引張強度, 剥離接着強度との関係を詳細に検討している。 その結果、耐剥離性と接着引張強度, 剥離接着強度の関係は希薄で あることを指摘するとともに、耐剥離性からみた床下地の良否の序 列は、キャスターによる荷重の接地圧が低く摩擦卜ルクが大きい場 合表面強度によりおおよそ説明できるのに対し、接地圧が高く摩擦 トルクが小さい場合圧縮強度によりおおよそ説明でき、かつ表面粗 さの影響も明確であることを明らかにしている。しかし、耐剥離性 の観点から床下地の品質を定量的に評価するためには、さらなる検 討が必要と述べている。

一方、横山らは、JIS A 1450 「フリーアクセスフロア試験方法」5) に規定されたローリングロード試験機を用い、キャスターが直進お よび発進, 停止する際の動荷重に対する塗り床の耐久性について検 討している。具体的には、コンクリート打ち込み後の上面仕上げ作 業や養生の方法を種々変化させた床下地に塗り床材を施工した試験 体を対象に、上記動荷重を繰り返し作用させたときに塗り床に剥離 が発生するまでの往復回数を求め、床下地の表面強度および施工方 法との関係を検討している。その結果、塗り床材の種類, 塗り厚お よび動荷重の大きさ，性状など限られた条件ではあるが、施工現場 で適用可能な表面強度の管理指標を、剥離を発生させないための施 工方法とともに提示している。本研究は、塗り床にとってより過酷 と思われるキャスターが曲折する際の動荷重を対象に、同様の検討 を行うものである。

\section{4. 研究方法}

本研究の研究方法を、以下に示す。

1）床スラブを模擬した型枠にコンクリートを打ち込み、所定の方 法で上面仕上げ作業および養生を行って、床下地試験体を作製 する。

2）1）で作製した試験体の表層部の水分量を適宜測定し、所定の值 まで乾燥した段階で、表面強度をはじめとする各種表層部品質 を測定する。
3）表層部品質測定後、塗り床材を施工する。ここで、一部の試験 体では、塗り床材施工前に床下地表面にポリッシャ掛けを行い、 再度表層部品質を測定した後、塗り床材を施工寸る。

4）塗り床材施工後、十分な養生期間を経た後、キャスター曲折時 を模擬した動荷重を床に繰り返し作用させることができる試験 機を用いて耐動荷重性試験を実施し、塗り床に剥離が発生する までの繰り返し回数を測定する。また、JIS A 5536「床仕上げ 材用接着剂」 ${ }^{6)}$ に準拠した引張接着強さ試験を実施し、引張接 着強さを測定する。

5） 4) で測定した繰り返し回数と、2)で測定した表面強度をはじめ とする各種表層部品質との関係、および1)における床下地の施 工方法との関係に基づいて、初期不具合を発生させないために 必要な表層部品質を、それを具現するための施工方法とともに 提示する。また、4)で測定した引張接着強さと表層部品質, 施 工方法および繰り返し回数との関係も考察する。

\section{5. 試験概要}

\section{1 試験体の作製および試験手順}

Fig. 1 に、試験体の例を示す。試験体の大きさは、コンクリート 打ち込み後の上面仕上げ作業が無理なく行えること、および而動荷 重性試験もしくは引張接着強さ試験が実施できることなどを考慮し て、 $300 \times 300 \mathrm{~mm}$ (耐動荷重性試験用) もしくは $450 \times 450 \mathrm{~mm}$ (引張接着 強さ試験用) とし、コンクリートの厚さは $75 \mathrm{~mm}$ (一部 $100 \mathrm{~mm})$ とした。

Table 1 に、試験体の作製条件を示す。表に示すNo. 1 43の43種 の条件で、試験体を作製した。試験体の作製は、表の「グループ」 の欄に示す 1 ～ 8 のグループごとに、番号順に実施した。グループ3 以降の試験体の作製条件は、それ以前のグループの試験結果を受け て適宜設定したものである。試験体は、条件ごとに6体作製した。6 体の内訳は、後述の通り、塗り床材の塗り厚 2 種 $(0.8 \mathrm{~mm}$ と $2.0 \mathrm{~mm}) \times\{$ 耐

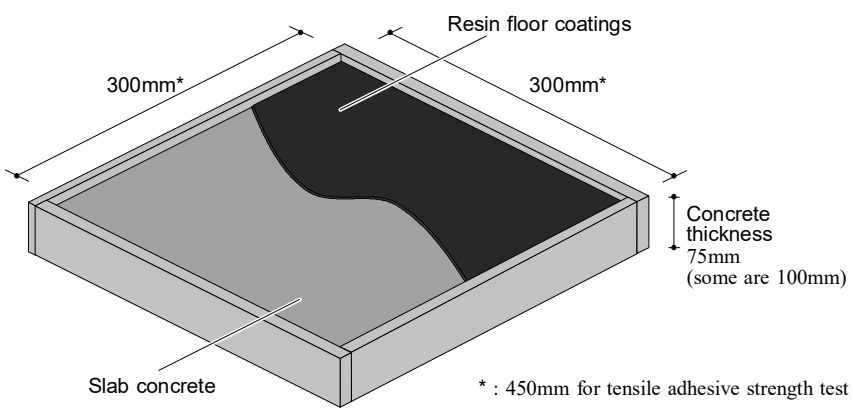

Fig. 1 Example of specimen ( For durability test against dynamic load)

Table 1 Preparation conditions for specimens

\begin{tabular}{|c|c|c|c|c|c|c|c|c|c|c|c|c|c|c|c|c|c|c|c|c|}
\hline $\begin{array}{c}\text { Specimen number } \\
\text { [圾験体No] }\end{array}$ & 2 & 3 & 5 & 7 & 9 & & \begin{tabular}{|l|l|}
13 & 14 \\
\end{tabular} & \begin{tabular}{|l|l|}
15 & 16 \\
\end{tabular} & 1718 & 1920 & 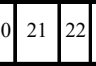 & \begin{tabular}{|l|l|}
23 & 24 \\
\end{tabular} & \begin{tabular}{|l|l|}
425 & 26 \\
\end{tabular} & \begin{tabular}{|l|l|}
627 & 28 \\
\end{tabular} & \begin{tabular}{|l|l|l|l|}
29 & 30 & 31 & 32 \\
\end{tabular} & \begin{tabular}{|l|l|}
23 & 34 \\
\end{tabular} & 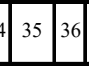 & \begin{tabular}{|l|l|}
37 & 38 \\
\end{tabular} & \begin{tabular}{|l|l|}
39 & 40 \\
\end{tabular} & \begin{tabular}{|l|l|l|}
41 & 42 & 43 \\
\end{tabular} \\
\hline $\begin{array}{c}\text { Group } \\
{[\text { グループ] }}\end{array}$ & & & 1 & & & & 2 & & 3 & & & 4 & & 5 & & 6 & & & 7 & 8 \\
\hline $\begin{array}{c}\text { Concrete } \\
{[\text { [コンクリート }]}\end{array}$ & & & & & $36-15$ & & & & & & $30-18-$ & $8-20 \mathrm{~N}$ & & $\begin{array}{l}36-15- \\
20 \mathrm{~N}\end{array}$ & & & $-18-20 \mathrm{~N}$ & & & $\begin{array}{l}36-15- \\
20 \mathrm{~N}\end{array}$ \\
\hline $\begin{array}{c}\text { Worker of finishing } \\
\text { [上面仕上げ作業者] }\end{array}$ & & & A & & & & B & & & & & D & & B & & D & & & $\mathrm{C}$ & B \\
\hline $\begin{array}{c}\text { Finishing work condition } \\
\text { [施工条件] }\end{array}$ & I & II & $\mathrm{II}^{+}$ & III & I & II & $\mathrm{II}^{+}$III & $\mathrm{II}^{+} \mathrm{II}$ & $\mathrm{II}^{+}$ & I II & I II III & I II & II $^{+}$III & II II $^{+}$ & \begin{tabular}{|l|l|l|l|l|} 
I & II & I & III \\
\end{tabular} & I II & II + III & $\mathrm{II}^{+} \mathrm{II}$ & I I I II & $\mathrm{II}^{+}$ \\
\hline $\begin{array}{c}\text { Moisture meter reading } \\
\text { [水分計指示値] }\end{array}$ & & & 5 & & & 5 & & 6 & \begin{tabular}{|l|l|}
5 & 6
\end{tabular} & & 5 & & 6 & 5 & 5 & & 6 & 5 & 6 & 5 \\
\hline $\begin{array}{c}\text { Do polish or not } \\
\text { [ポリッシャ掛けナの有無 }]\end{array}$ & 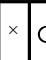 & & & & & 1 & \begin{tabular}{|l|l|}
0 & 0 \\
\end{tabular} & \begin{tabular}{|l|l|}
0 & 0 \\
\end{tabular} & 00 & 11 & 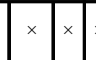 & \begin{tabular}{|l|l|}
$\times$ & $\times$ \\
\end{tabular} & \begin{tabular}{l|l|}
$\times$ & $\times$ \\
\end{tabular} & $\begin{array}{lll} & 0 & 0 \\
\end{array}$ & \begin{tabular}{l|l|l|l|}
0 & 0 & 0 & 0 \\
\end{tabular} & 00 & \begin{tabular}{l|l|l|}
0 & 0 \\
\end{tabular} & $\times$ & $\times$ & $\times 100$ \\
\hline
\end{tabular}


Table 2 Summary of concrete

\begin{tabular}{|c|c|c|c|c|c|}
\hline $\begin{array}{c}\text { Group } \\
{[\text { [グループ] }}\end{array}$ & $\begin{array}{c}\text { Concrete } \\
\text { [コンクリート] }\end{array}$ & $\begin{array}{l}\text { Water-to-binder ratio } \\
\text { [水セメント比] } \\
\end{array}$ & $\begin{array}{l}\text { Water content } \\
\text { [単位水量] }(\%) \\
\end{array}$ & $\begin{array}{l}\text { measurement slump } \\
\text { [実測スランプ] (cm) }\end{array}$ & $\begin{array}{l}\text { compressive strength } \\
\text { [圧縮強度] }\left(\mathrm{N} / \mathrm{mm}^{2}\right)\end{array}$ \\
\hline $1,2,3$ & $36-15-20 \mathrm{~N}$ & 45 & 160 & 15.5 & 39.6 \\
\hline 4 & $30-18-20 \mathrm{~N}$ & 49 & 186 & 19.5 & 35.5 \\
\hline 5 & $36-15-20 \mathrm{~N}$ & 45 & 160 & 16.0 & 41.7 \\
\hline 6,7 & $30-18-20 \mathrm{~N}$ & 49 & 186 & 17.0 & 37.1 \\
\hline 8 & $36-15-20 \mathrm{~N}$ & 45 & 160 & 16.5 & 40.8 \\
\hline
\end{tabular}

Table 3 Summary of finishing work conditions

\begin{tabular}{|c|c|c|c|c|}
\hline & \multicolumn{2}{|c|}{$\begin{array}{l}\text { Finishing times } \\
\text { [仕上げ回数 }]\end{array}$} & \multirow{2}{*}{$\begin{array}{l}\text { Curing } \\
\text { [養生] }\end{array}$} \\
\hline & & $\begin{array}{l}\text { Smoothing } \\
\text { [むら直し] } \\
\end{array}$ & $\begin{array}{c}\text { Troweling } \\
\text { [押え] }\end{array}$ & \\
\hline \multirow{4}{*}{$\begin{array}{l}\text { Finishing } \\
\text { work } \\
\text { conditions } \\
\text { [施工条件] }\end{array}$} & $\begin{array}{|cc|}1 & \text { (Poor condition) } \\
& \text { [劣悪な条件] } \\
\end{array}$ & \multirow{3}{*}{ Once } & Once & Waterless \\
\hline & 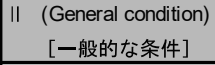 & & \multirow{2}{*}{ Twice } & [気中養生] \\
\hline & $\begin{array}{c}11+\text { + ( II + Water curing }) \\
\text { [ II +散水養生 }]\end{array}$ & & & \multirow{2}{*}{$\begin{array}{c}\text { Water curing (3 days) } \\
\text { + waterless curing } \\
\text { [散水盖生 ( } 3 \text { 日間) } \\
\text { +気中養生 }]\end{array}$} \\
\hline & 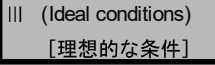 & Twice & 3 times & \\
\hline
\end{tabular}

Table 4 Grade of surface strength ${ }^{8), 9)}$

\begin{tabular}{|c|c|}
\hline Grade & Scratch width $(\mathrm{mm})$ \\
\hline $\mathrm{I}$ & Less than 0.3 \\
\hline $\mathrm{II}$ & 0.3 or more and less than 0.55 \\
\hline III & 0.55 or more and less than 0.7 \\
\hline IV & 0.7 or more \\
\hline
\end{tabular}

動荷重性試験用2体 (載荷荷重5000N用と10000N用) +引張接着強さ試 験用 1 体 $\}$ となっている。

使用するコンクリートは、表の「コンクリート」の欄に示す通り、 物流施設や生産施設の床スラブに一般的に用いられる「普通36-15$20 \mathrm{~N} 」 と 「$ 普通30-18-20N」の2種とした。使用したコンクリートの 水セメント比, 単位水量, 実測スランプおよび圧縮強度をTable 2 に示す。また、コンクリート打ち込み後の上面仕上げ作業の作業者 は、表の「上面仕上げ作業者」の欄に示す通り、A〜Dの4名とした。 4名とも上面仕上げ作業の経験者であるが、作業者Dは、他の3名と 比較して作業時に鏝に掛ける力が弱いことが、作業の観察結果から 推察された。

上面仕上げ作業時の鏝掛けの回数とその後の養生の方法は、表の 「施工条件」の欄に示す I , II , II +, III の4種とした。Table 3 に、各施工条件の概要を示す。これらは、横山ら ${ }^{7)}$ が施工管理者や 上面仕上げ作業担当者らを対象に実施した施工現場における実状調 査結果を参考に設定したもので、I は劣悪な条件、II は一般的な条 件、II + はII の養生の方法を気中養生のみから 3 日間散水養生後気 中養生に変更した条件、III は理想的な条件と位置付けられるもので ある。

上面仕上げ作業が終了した試験体は、温度 $20 \pm 2{ }^{\circ} \mathrm{C}$ ，湿度 $60 \pm 5 \%$ の実験室にて、所定の方法で養生した。各試験体について、気中養 生開始後、表層部の水分量を高周波静電容量式水分計(ケット科学 研究所製HI-520-2) で適宜測定し、指示值が Table 1 の「水分計指

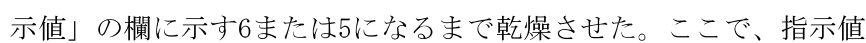
6は、日本床施工技術研究協議会「コンクリート床下地表層部の諸 品質の測定方法，グレード」 ${ }^{8), 9)}$ に規定された水分量のグレード II b とIIIの境界に、指示值5は、グレードII a と II bの境界に該当する。 日本塗り床工業会「塗り床ハンドブック」10)では、指示值5以下、
すなわちグレードII a以上まで床下地を 乾燥させることを推奨している。

各試験体がそれぞれ所定の指示值まで 乾燥した段階で、5.2で述べる表層部品 質の測定を実施した。測定後、Table 1 の「ポリッシャ掛けの有無」の欄に○を 記した試験体では、表面にポリッシャ(\# 24）掛けを行い、その後再度表層部品質 を測定した。以降、ポリッシャを掛けた試験体を“P有”(図中では “P○”)、掛けていない試験体を“P無”(図中では“P×”) と記す。

表層部品質の測定後、塗り床材を施工した。塗り床材は、物流施 設や生産施設の床で最も普及しているものの1つであるエポキシ樹 脂系1種とし、塗り厚は $0.8 \mathrm{~mm}$ と $2.0 \mathrm{~mm}$ の種とした。施工は、はじめ にプライマーを規定量塗布し、規定の乾燥時間経過後、ベースコー トを金鏝で流し延べる工法で施工した。ベースコートの塗り厚は、 使用する材料の重量で管理した。

塗り床材施工後、各試験体を温度 $20 \pm 2{ }^{\circ} \mathrm{C}$, 湿度 $60 \pm 5 \%$ の実験室 に4週間以上静置した後、5.3で述べる引張接着強さ試験および 5.4 で述べる耐動荷重性試験を実施した。

\section{2 床下地表層部品質の測定}

\section{(1) 表面強度}

土田ら ${ }^{11)-13)}$ が開発し、日本床施工技術研究協議会「コンクリー 卜床下地表層部の諸品質の測定方法，グレード」 ${ }^{8), 9)} に$ 規定された 引っかき試験器法にしたがって、表面強度を測定した。この方法は、 床下地表面に先端角 $90^{\circ}$ の尖りピンを加圧力 $9.8 \mathrm{~N}$ で押し付けて長さ $10 \mathrm{~cm}$ 程度引っかいた際の “引っかき傷幅”を測定するもので、傷幅 が小さいほど表面強度が高いことを表す。Table 4 に、上記協議会 が規定する表面強度のグレードを示す。

測定は、1試験体につき3箇所で実施し、1本の引つかき傷から3箇 所、計9個の引っかき傷幅の平均を求めた。

\section{(2) 放出水分量}

水分計指示值は、床下地表層部に含まれる水分の量を概略推定し た指標である。これに対し、剥離発生の原因となり得る床下地と塗 り床材の接着力の低下に直接的に影響するのは、床下地表面から放 出されてくる水分の量 (以降 “放出水分量” と記す) と考えられる。 よって、本研究では、放出水分量も測定することとした。測定は、 湯浅ら ${ }^{14)}$ が開発し、前述の「測定方法, グレード」 ${ }^{8), 9)}$ に規定され た乾燥度試験紙法にしたがって実施した。具体的には、藤井ら 15)を 参考に、湿気に反応して色が変化する乾燥度試験紙 (ADVANTEC製) を 不透湿性透明テープを用いて床下地表面に貼り付け、10分後の色を 標準変色表と照合して “変色表值”を求めた。変色表值が小さいほ ど放出水分量が少ないことを表す。乾燥度試験紙の測色には、色彩・ 色差計 (コニカミノルタ製 $\mathrm{CR}-400$ )を用いた。

測定は、1試験体につき3箇所で実施し、3個の変色表值の平均を 求めた。

\section{(3) 表面粗さ}

P有の試験体の一部 (No. 29〜36，42，43)では、ポリッシャ掛けの 前後に、表面粗さを測定した。測定には、触針式表面粗さ計(ミッ トヨ製S J-210）を用い、測定長さ $5 \mathrm{~mm}$ ，触針送り速度 $0.5 \mathrm{~mm} / \mathrm{s}$ ，カッ

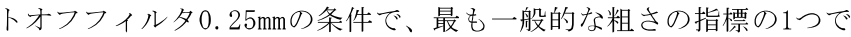




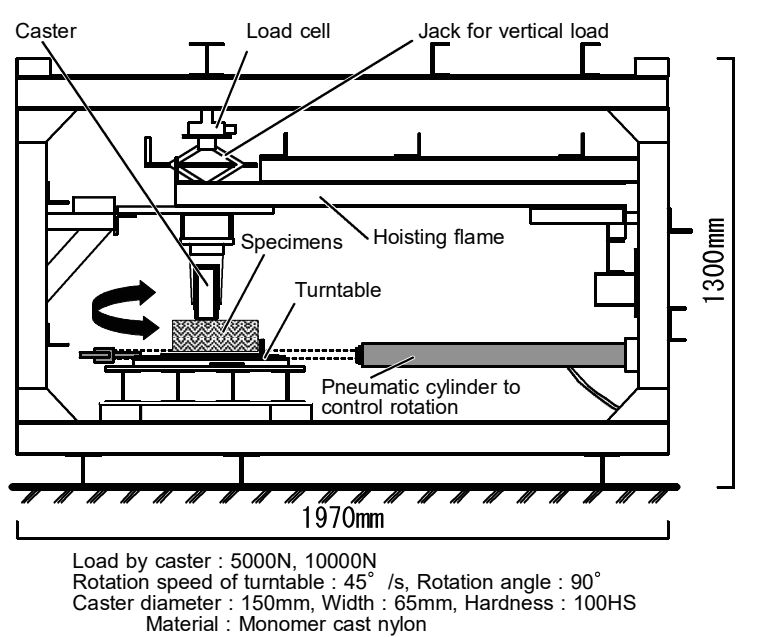

Fig. 2 Summary of twist load tester ${ }^{17)}$

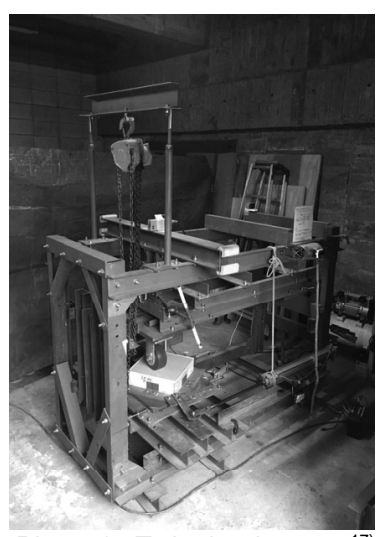

Photo 1 Twist load tester ${ }^{17}$

ある“二乗平均平方根粗さ”16)を測定した。

測定は、 1 試験体につき 5 箇所で実施し、5個の二乗平均平方根粗 さの平均を求めた。

\section{3 引張接着強さ試験}

塗り床の接着力の評価に広く用いられている、JIS A 5536 「床仕 上げ材用接着剂」 ${ }^{6}$ に準拠した引張接着強さ試験を実施した。本試 験は、塗り床表面に接着した $40 \times 40 \mathrm{~mm}$ の鋼製アタッチメントを鉛直 方向に引っ張り上げたときの荷重を測定するもので、塗り床破壊時 までの荷重の最大值をアタッチメントの接着面積で除した值を“引 張接着強さ”として求めた。ここで、アタッチメント周囲には、床 下地表層部を含めた強度を把握する目的で、床下地表面より $5 \mathrm{~mm}$ 程 度の深さの溝を施した。
試験は、各試験体につき5箇所で実施し、5個の引張接着強さの平 均を求めるとともに、破壊が発生した層を確認した。

\section{4 耐動荷重性試験}

而動荷重性試験には、筆者らと建築床特殊性能研究会が開発した、 キャスター曲折時を模擬した動荷重を床に繰り返し作用させること ができる“ひねり荷重試験機”17)を用いた。Fig. 2 および Photo 1 に、ひねり荷重試験機の概要を示す。本試験機は、回転台上に設置 した試験体に所定の鉛直荷重を載荷したキャスターを載せ、回転台 を回転往復させることで塗り床に剥離を発生させるものである。 キャスターの載荷位置の中心は、回転台の回転軸から $50 \mathrm{~mm}$ 偏心した 位置となっている。

本試験機の開発にあたっては、搬送車をはじめとする種々の機器 に使用されるキャスターのメーカの技術開発担当者にヒアリングを 行った。その結果、以下の事項が明らかとなった。

・物流施設や生産施設で使用される搬送車などのキャスターに作用 寸る鉛直荷重は、近年増大傾向にあり、現在では1輪あたり $40000 \mathrm{~N}$ 程度の鉛直荷重に耐えられるキャスターも開発されている。もち ろんこれは極端な例であるが、10000N程度までは、一般的な設計 の範囲内となっている。

・キャスターの耐久性を検討する場合、より過酷な条件として、曲 線通過時の、接地面の内側と外側でキャスターに作用する荷重が 異なる状況を想定する必要がある。接地面の床にはキャスターの 反力が作用するので、床の耐久性を検討する場合にも、同様の状 況を想定する必要があると考えられる。

・キャスターの材質は、作用する鉛直荷重の増大にともない、ゴム や鋼に代わり、硬さ90〜100HSのウレタン樹脂や硬質ナイロンが 主流になっている。

本試験機は、以上のヒアリング結果を参考に、開発したものであ る。

本試験機を用いた耐動荷重性試験の試験条件の詳細は、眓に示寸 通りである。キャスターに載荷する鉛直荷重は、一般的な搬送車の 1 輪に作用する荷重を想定した $5000 \mathrm{~N}$ と、大型の搬送車の 1 輪に作用 する荷重を想定した $10000 \mathrm{~N} の 2$ 種とした。また、キャスターは、上

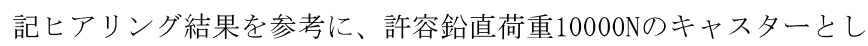
て普及しているものの 1 つである、直径 $150 \mathrm{~mm}$ ，幅 $65 \mathrm{~mm}$ ，硬さ $100 \mathrm{HS}$ の硬質ナイロン製のものとした。

試験開始後、以下に示す往復回数ごとに打診棒を用いてキャス ターの走行位置およびその周辺における剥離発生の有無を確認し、

剥離が発生した場合、その往復回数を “剥離発生往復回数”として求 $\begin{array}{llllllllllllllllllllllllllllllllllllllllllllllll}\begin{array}{l}\text { Specimen } \\ \text { number }\end{array} 1 & 2 & 3 & 4 & 5 & 6 & 7 & 8 & 9 & 10 & 11 & 12 & 13 & 14 & 15 & 16 & 17 & 18 & 19 & 20 & 21 & 22 & 23 & 24 & 25 & 26 & 27 & 28 & 29 & 30 & 31 & 32 & 33 & 34 & 35 & 36 & 37 & 38 & 39 & 40 & 41 & 42 & 43\end{array}$

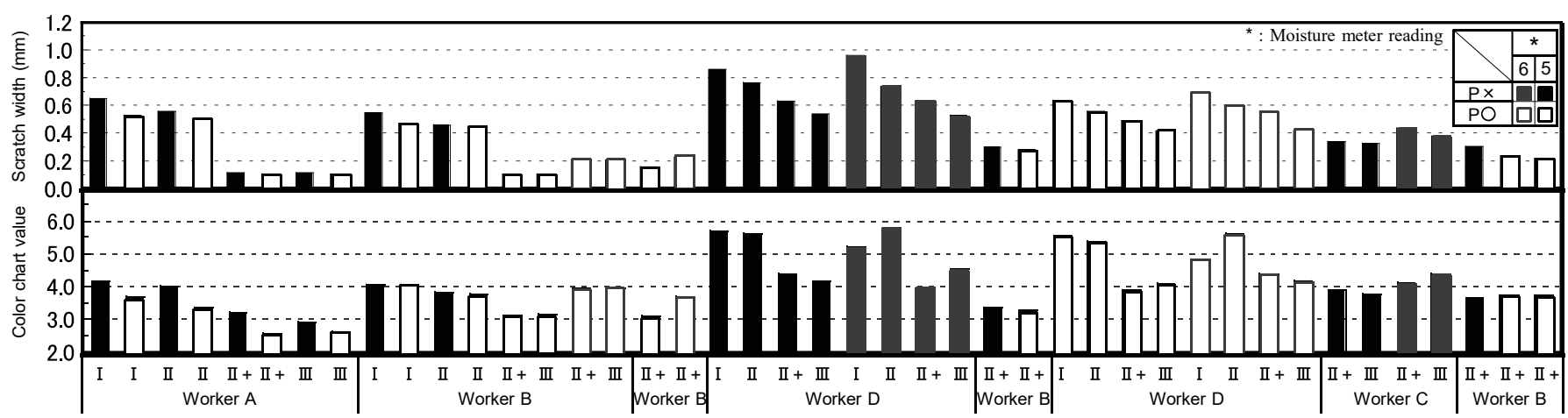

Fig. 3 Measurement results of scratch width and color chart value 

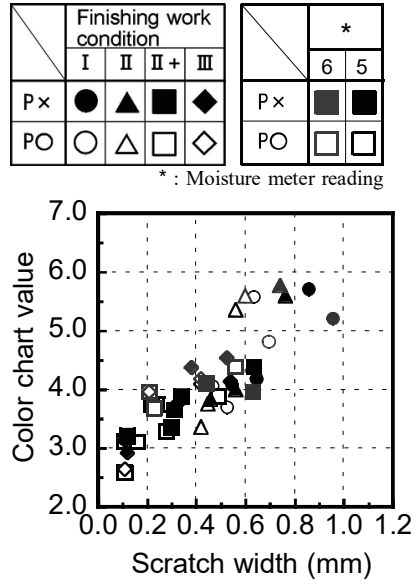

Fig. 4 Relationship between color chart value and scratch width

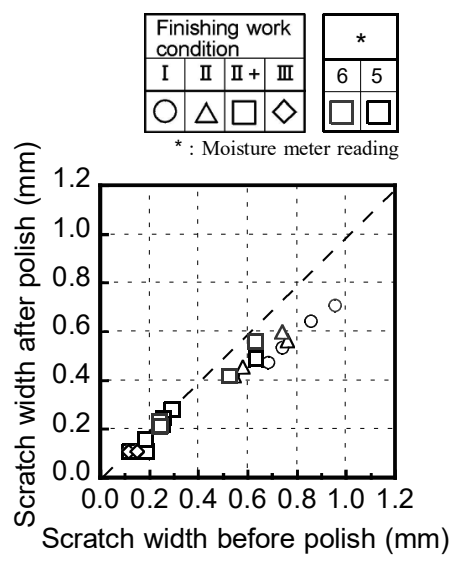

Fig. 5 Scratch width relationship before and after polish

めるとともに、破壊が発生した層を確認した。なお、本研究は初期

不具合を対象としていることから、最大往復回数は 300 往復とした。

$$
\begin{aligned}
& \text { ・0〜30往復：2往復ごと } \\
& \text { ・31〜 60往復：5往復ごと } \\
& \text { • } 61 \text { 〜 } 100 \text { 往復 : } 10 \text { 往復ごと } \\
& \text { ・101〜300往復：20往復ごと }
\end{aligned}
$$

\section{6. 床下地表層部品質の測定結果および考察}

Fig. 3 に、引っかき傷幅および変色表值の測定結果を示す。図に は、作製条件が同一の6体の試験体での測定結果の平均を示した。 ここで、P有の試験体では、ポリッシャ掛け後の測定結果を示して いる。

図より、以下に示す、コンクリート，上面仕上げ作業者，水分計 指示値，ポリッシャ掛けの有無が同一で施工条件のみが異なる試験 体の組み合わせごとに結果を比較すると、施工条件が I $\rightarrow$ II $\rightarrow$ II + 十III と向上するにしたがって、引っかき傷幅および変色表值が小さ くなる、すなわち表面強度が高く、放出水分量が少なくなる傾向が 明確に把握できる。特に、散水養生を行わなかった I , II と、行っ た II + ， IIII差が、大きくなっている。

• No. 1 と 3 と 5 と 7

• No. 2 と 4 と 6 と 8

- No. 10 と 12 と 13 と 14

• No. 19 と 20 と 21 と 22
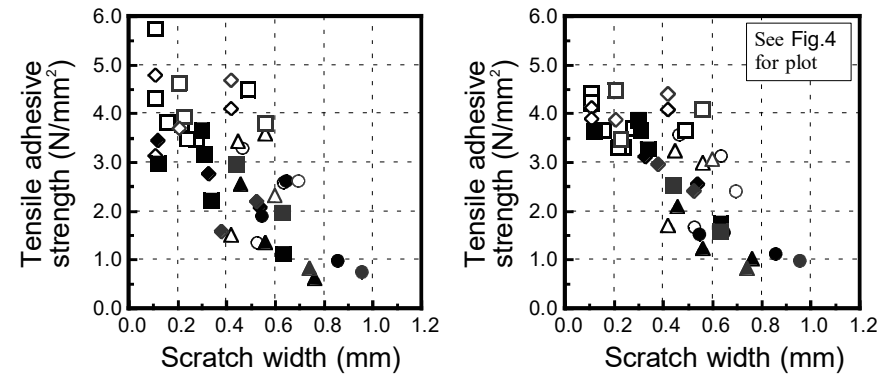

[A] Coating thickness : $0.8 \mathrm{~mm}$

[B] Coating thickness : $2.0 \mathrm{~mm}$

Fig. 7 Relationship between tensile adhesive strength and scratch width (part 1)

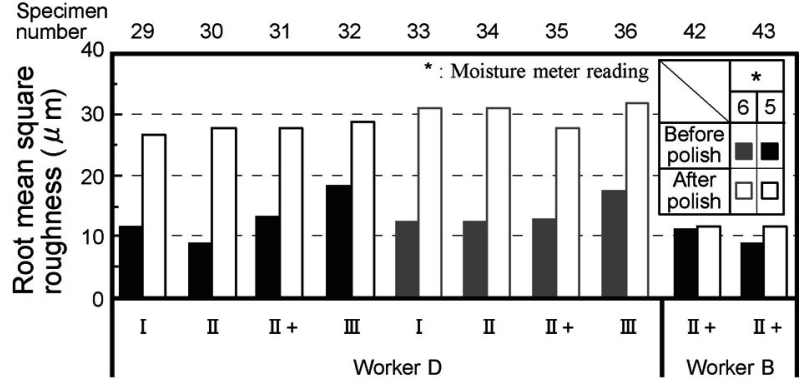

Fig. 6 Root mean square roughness before and after polish
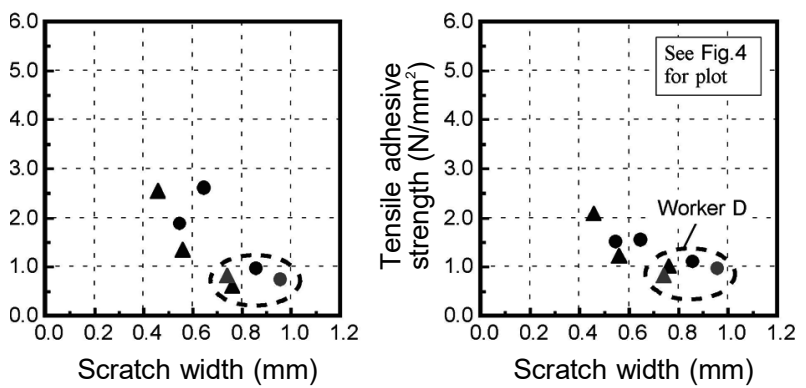

(1) Waterless curing, $\mathrm{Px}$

(1) Waterless curing, $\mathrm{Px}$
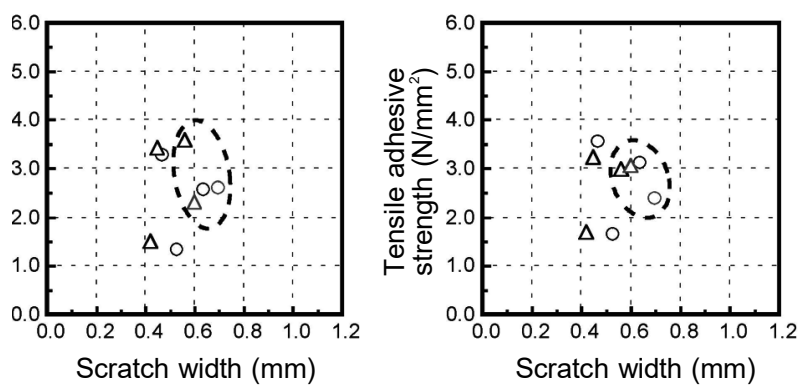

(2) Waterless curing, $\mathrm{PO}$

(2) Waterless curing, $\mathrm{PO}$

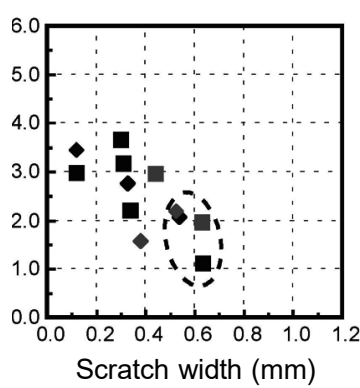

(3) Water curing, $\mathrm{Px}$

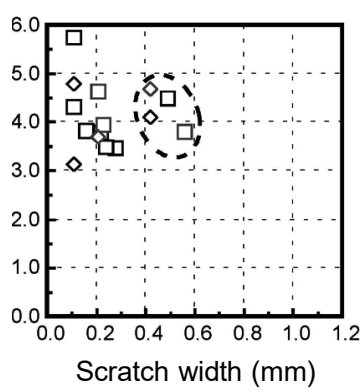

(4) Water curing, $\mathrm{PO}$

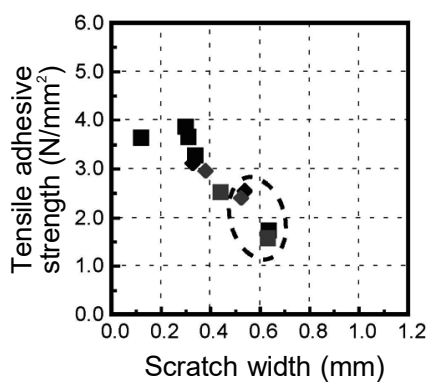

(3) Water curing, $\mathrm{Px}$

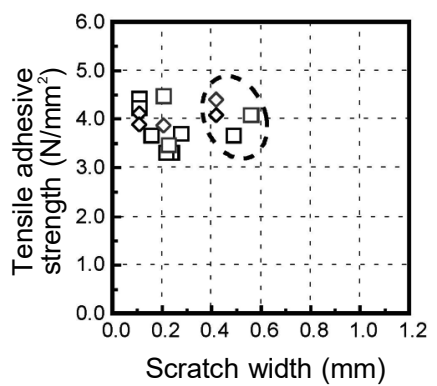

(4) Water curing, PO

[B] Coating thickness : $2.0 \mathrm{~mm}$

[A] Coating thickness : $0.8 \mathrm{~mm}$

Fig. 8 Relationship between tensile adhesive strength and scratch width (part 2) 


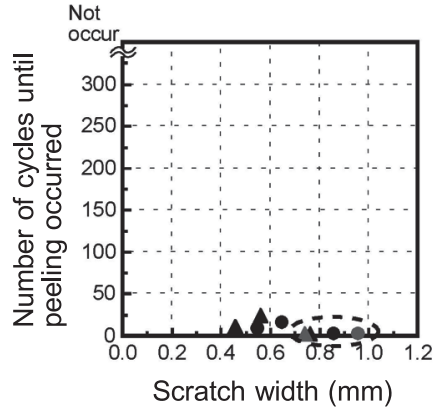

(1) Waterless curing, $P \times$

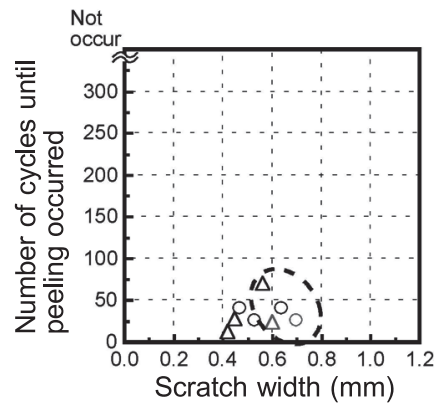

(2) Waterless curing, $\mathrm{PO}$

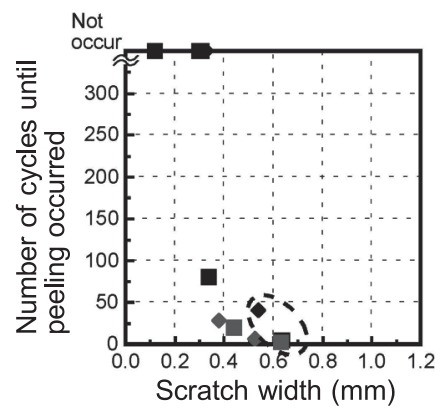

(3) Water curing, $P \times$

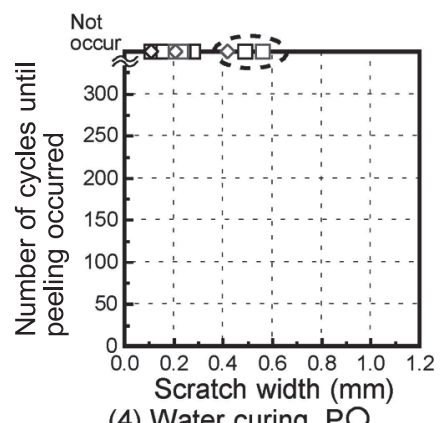

(4) Water curing, PO

[A] Coating thickness : $0.8 \mathrm{~mm}$

Fig. 9 Relationship between number of cycles until peeling occurred and scratch width (5000N loading)

- No. 23 と 24 と 25 と 26

- No. 29 と 30 と 31 と 32

- No. 33 と 34 と 35 と 36

また、作業者のみが異なるNo. 21 と 37,22 と 38,25 と 39,26 と 40 の比較から、他の作業者と比較して鏝に掛ける力が弱いと推察され た作業者Dでの引っかき傷幅および変色表値は、作業者 $\mathrm{C}$ よ大きい 傾向が把握できる。

Fig. 4 に、変色表值と引っかき傷幅の関係を示す。図より、ばら つきはあるものの、引っかき傷幅が大きいほど変色表値も大きくな

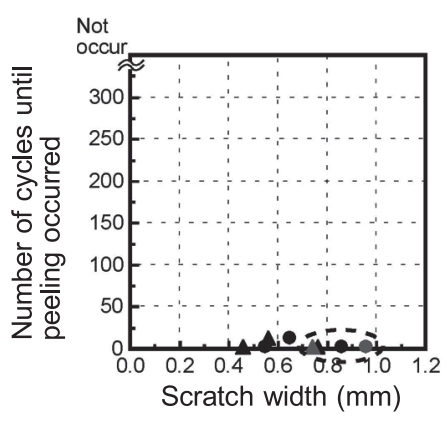

(1) Waterless curing, $\mathrm{Px}$

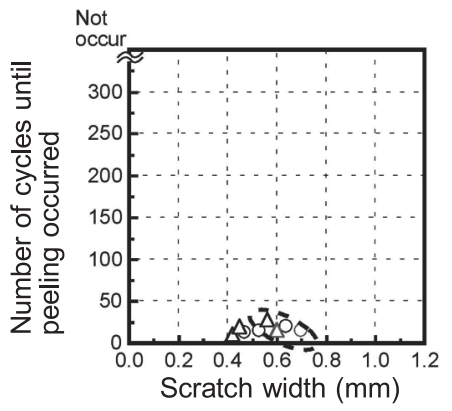

(2) Waterless curing, PO

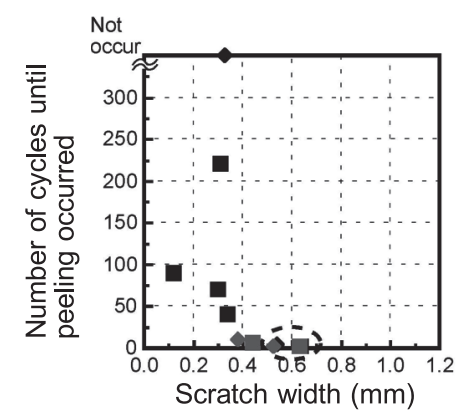

(3) Water curing, $P x$

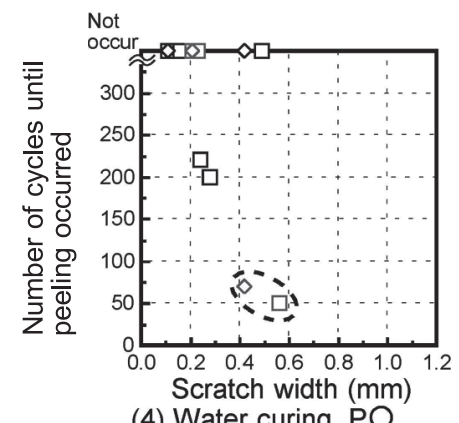

(4) Water curing, PO

[A] Coating thickness : $0.8 \mathrm{~mm}$

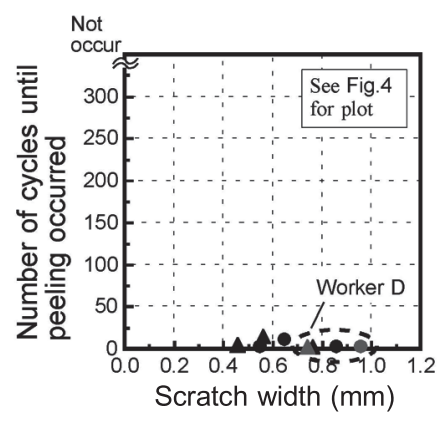

(1) Waterless curing, $P \times$

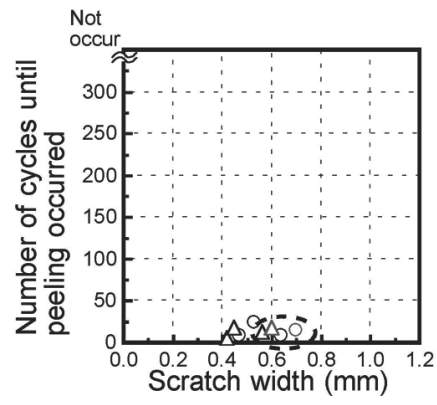

(2) Waterless curing, PO

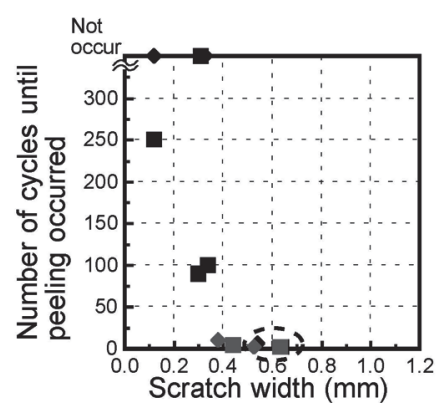

(3) Water curing, $P \times$

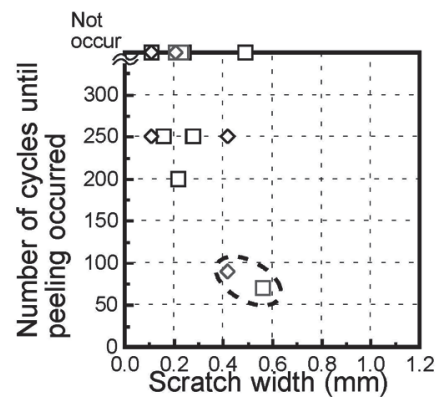

(4) Water curing, $\mathrm{PO}$

[B] Coating thickness : $2.0 \mathrm{~mm}$
Fig. 10 Relationship between number of cycles until peeling occurred and scratch width (10000N loading)

る、すなわち表面強度が大きいほど放出水分量が多くなる傾向が把 握できる。

つぎに、Fig. 5 に、P有の試験体で、ポリッシャ掛けの前後に測 定した引つかき傷幅の関係を示す。図より、ポリッシャ掛けにより 引っかき傷幅は小さくなる傾向があること、およびポリッシャ掛け 前後での差はポリッシャ掛け前の引っかき傷幅が大きいほど大きく なる傾向があることがわかる。これは、表面強度が低いほど、ポリッ シャ掛けにより表面の脆弱層が除去されやすいことによるものと思 われる。 


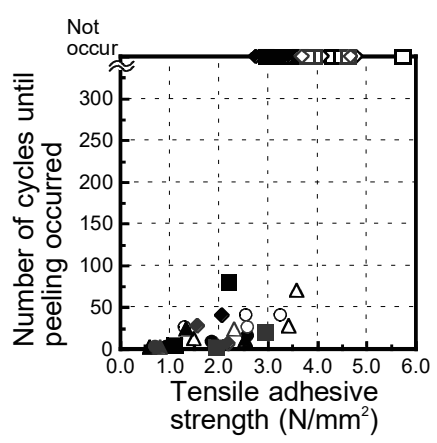

[A] Coating thickness : $0.8 \mathrm{~mm}$

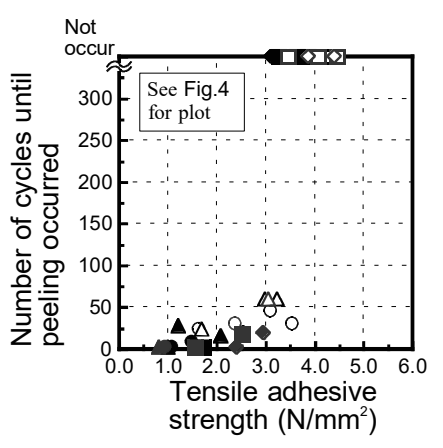

[B] Coating thickness : $2.0 \mathrm{~mm}$

Fig. 11 Relationship between number of to-and-fro that peeling occurred and Tensile adhesive strength (5000N loading)

Fig. 6 に、P有の試験体の一部 (No. 29〜36, 42，43)で、ポリッシャ 掛けの前後に測定した二乗平均平方根粗さを比較して示す。図より、 ポリッシャ掛けにより二乗平均平方根粗さは大きくなっていること がわかる。特に、作業者Dによる試験体ではポリッシャ掛け前後で の差が大きくなっているが、これは表面強度が低いため、表面が目 荒らしされやすいことによるものと思われる。

\section{7. 引張接着強さ試験結果および考察}

引張接着強さ試験の結果、各試験体の破壊層はいずれもコンク リート表層部であったことから、引張接着強さと床下地の表面強度 の関係について検討することとした。Fig. 7 に、引張接着強さと床 下地の引っかき傷幅の関係を示す。ここで、P有の試験体では、ポ リッシャ掛け後の引っかき傷幅を用いている。図の $[\mathrm{A}]$ は、塗り床 材の塗り厚0. $8 \mathrm{~mm}$ の場合、 $[\mathrm{B}]$ は2. $0 \mathrm{~mm}$ の場合の結果である。

図より、塗り厚 $0.8 \mathrm{~mm}$ の場合も $2.0 \mathrm{~mm} の$ 場合も、引つかき傷幅が小 さいほど引張接着強さが高くなる傾向が明確に把握できる。また、

○, $\boldsymbol{\Delta}, \boldsymbol{\square}, \diamond$ で示したP無の試験体と $, \triangle, \square, \diamond て ゙$ 示したP有 の試験体を比較すると、全体的傾向としてP有の試験体の方が上側 にプロットされており、同程度の引っかき傷幅に対する引張接着強 さはP有の方が高くなる傾向があることがわかる。これは、ポリッ シャ掛けにより床下地表面に凹凸が付与されたことによるアンカー 効果の影響と思われる。

以上の結果と、6. で述べた通り引つかき傷幅が散水養生を行わ なかった施工条件 I, II と行った II +, III で大きく異なったことに 基づき、以降、各試験体を散水養生の有無とポリッシャ掛けの有無 の観点から4種のグループに分類し、考察を進めることとした。

Fig. 8 に、引張接着強さと引つかき傷幅の関係を 4 種のグループご とに示す。図中、(1) は散水養生無, P無、（2）は散水養生無, P有、 （3）江散水養生有, P無、(4) は散水養生有, P有の試験体による結果 である。また、図中点線で囲んだ点は、作業者Dの試験体による点 である。

図に示すように、散水養生無の (1)，（2）ではいずれの試験体でも 引っかき傷幅は $0.4 \mathrm{~mm}$ 以上となっている。これに対し、散水養生有, $\mathrm{P}$ 無の (3) では、作業者Dによる試験体を除き大部分が $0.4 \mathrm{~mm}$ 未満と なっており、このうち、散水養生後の気中養生期間が比較的長い水 分計指示值 5 の試験体では、過半数が $0.3 \mathrm{~mm}$ 未満となっている。一方、 散水養生有, P有の (1) では、P無の (3) と比較して、引っかき傷幅の 分布範囲が小さい側に移動している。その結果、引っかき傷幅は、

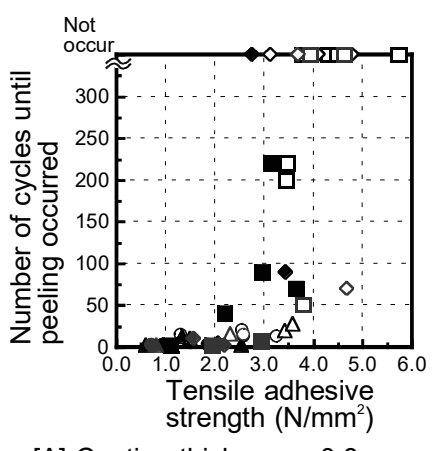

[A] Coating thickness : $0.8 \mathrm{~mm}$

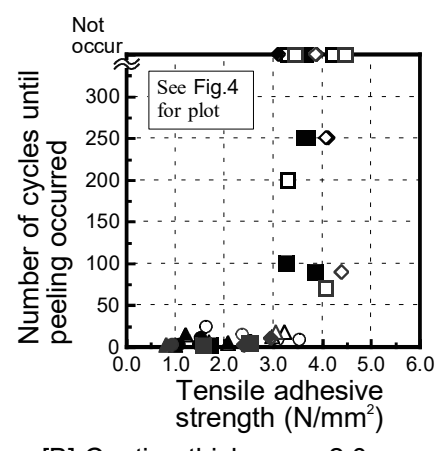

[B] Coating thickness : $2.0 \mathrm{~mm}$
Fig. 12 Relationship between number of to-and-fro that peeling occurred and Tensile adhesive strength (10000N loading)

作業者Dによる試験体を除き、いずれも $0.3 \mathrm{~mm}$ 未満となっている。

引張接着強さは、引っかき傷幅が $0.3 \mathrm{~mm}$ 未満 (Table 4 に示すグ レード I )であれば、塗り厚 $0.8 \mathrm{~mm}$ の場合も $2.0 \mathrm{~mm}$ 場合も、 $3 \mathrm{~N} / \mathrm{mm}^{2}$ 以上がほぼ確保されている。また、散水養生有, P有(4)では、作業 者によるる試験体では引っかき傷幅は $0.4 \mathrm{~mm}$ 以上であるものの、6. で述べた通りポリッシャ掛けによる表面目荒らしの効果も大きく、 結果として、全ての試験体で引張接着強さは $3 \mathrm{~N} / \mathrm{mm}^{2}$ 以上となって いる。

\section{8. 耐動荷重性試験結果および考察}

耐動荷重性試験の結果、各試験体の破壊層はいずれもコンクリー 卜表層部であったことから、剥離発生往復回数と床下地の表面強度 の関係について検討することとした。Fig. 9，10 に、剥離発生往 復回数と床下地の引っかき傷幅の関係を、散水養生の有無およびポ リッシャ掛けの有無で分類して示寸。Fig. 9 は載荷荷重5000Nの場 合、Fig. 10 は10000Nの場合の結果である。ここで、300往復終了時 点でも剥離が発生しなかった試験体は、「未発生」としてプロット してある。

図より、散水養生無の (1)，（2）では、剥離発生往復回数は載荷荷 重5000Nの場合多くても70往復、10000Nの場合28往復であり、初期 不具合が発生する可能性が高いことがわかる。一方、散水養生有, P無の (3) では、塗り厚0.8mmの場合も $2.0 \mathrm{~mm}$ の場合も、5000Nの場合 引っかき傷幅が $0.3 \mathrm{~mm}$ 未満であれば剥離は発生していないのに対し、 $10000 \mathrm{~N}$ 場合 $0.3 \mathrm{~mm}$ 未満でも多くの試験体で剥離が発生しており、 載荷荷重による負荷の違いが明確に表れている。さらに、散水養生 有, P有の (4) では、叙り厚0.8mmの場合も $2.0 \mathrm{~mm}$ の場合も、5000Nの 場合、引つかき傷幅が $0.3 \mathrm{~mm}$ 未満の試験体だけでなく、0.3m以上の 作業者Dによる試験体でも、ポリッシャ掛けによる表面目荒らしの 効果で剥離は発生していない。しかし、10000 Nの場合、0.3mm未満 では過半数の試験体で剥離は発生していないのに対し、0.3mm以上 では半数の試験体で100往復に達する前に剥離が発生している。

以上より、初期不具合を発生させないための目安として、載荷荷 重5000N程度の動荷重に対しては、むら直し1回, 押え2回以上の上 面仕上げ作業を行った後、散水養生を行い、さらに十分な気中養生 期間を設けることにより、引っかき傷幅 $0.3 \mathrm{~mm}$ 未満(Table 4 に示す グレード I ) の表面強度を確保すれば、初期不具合が発生する可能 性は低くなることが明らかとなった。また、10000N程度の動荷重に 対しては、上記に加えポリッシャを掛けて表面を目荒らしすること 
により、初期不具合が発生する可能性は低くなることが明らかと なった。さらに、上面仕上げ作業の際作業者が鏝に掛ける力が不足 して引っかき傷幅が $0.3 \mathrm{~mm}$ 未満とならなかった場合でも、 $5000 \mathrm{~N}$ 程度 の動荷重に対しては、ポリッシャを掛けて表面を目荒らしすること により、初期不具合が発生する可能性は低くなることが明らかと なった。

なお、キャスターが直進および発進, 停止する際の動荷重を対象 とした横山ら (1) では、引っかき傷幅0. $55 \mathrm{~mm}$ 未満 (Table 4 に示寸グ レードII 以上)の表面強度が確保されていれば剥離が発生する可能 性は低いとの結果が得られているが、キャスターが曲折する際の動 荷重を対象とした本研究では、上記の通りより高い表面強度が必要 との結果が得られており、塗り床にとってより過酷な動荷重である ことが確認できる。

最後に、Fig. 11, 12 に、剥離発生往復回数と引張接着強さの関 係を示す。三上, 坂井ら 2),3) が指摘している通り、耐動荷重性と静 的でかつ荷重の方向などが大きく異なる引張接着強さの関係は、本 来稀薄と思われる。本研究でも、図に示す通り、引張接着強さを用 いて初期不具合を発生させないための目安を提示するのは困難であ ることを示す結果が得られたが、逆に、 $3 \mathrm{~N} / \mathrm{mm}^{2}$ 程度以下の場合、初 期不具合が発生する可能性が非常に高いことが明らかとなった。

\section{9. おわりに}

キャスターが曲折する際の動荷重を対象に、塗り床の耐動荷重性 と床下地の表層部品質の関係について、床下地の施工方法を要因と して実験的に検討した本研究の結論は、以下の通りである。

・ 床下地の表面強度には、コンクリート打ち込み後の散水養生の 有無が大きく影響する。

・ 床下地にポリッシャを掛けると、表面の脆弱層が除去され表面 強度が高くなるとともに、表面が目荒らしされアンカー効果が 増すことにより、塗り床材施工後の耐動荷重性は向上する。こ の影響は、表面強度が低い床下地ほど顕著である。

・載荷荷重5000N程度の動荷重に対しては、むら直し1回, 押え2 回以上の上面仕上げ作業を行った後、散水養生を行い、さらに 十分な気中養生期間を設けることにより、引っかき傷幅 $0.3 \mathrm{~mm}$ 未満の表面強度を確保すれば、初期不具合が発生する可能性は 低くなる。また、10000N程度の動荷重に対しては、上記に加え ポリッシャを掛けて表面を目荒らしすることにより、初期不具 合が発生する可能性は低くなる。

ただし、以上の結果は、あくまでも床下地に用いるコンクリート、 塗り床材の種類, 塗り厚および動荷重の大きさ, 性状などを物流施 設や生産施設における一般的な条件に限定したうえで得られた結果 であり、仕様が大きく異なるコンクリート，塗り床材および動荷重 を対象とした場合などは、別途同様の検討が必要である。

\section{謝辞}

本研究を進めるにあたり、貴重な御助言をいただくとともに種々 御協力いただいた建築床特殊性能研究会および日本床施工技術研究 協議会の関係各位、ならびに清水建設株式会社竹本喜昭氏に、謝意 を表します。

\section{参考文献}

1) Hiroki TAKAHASHI, Teruo YAMAMIYA, Yutaka YOKOYAMA: Fundamental study on the specifications and execution of concreteslabs and finishing materials that interacting on floor performance. - In case of floor coating and resilient floorcoverings -Summaries of Technical Papers of Annual Meeting, Architectural Institute of Japan, Materials and Construction, pp. 861-862, 2019. 7

高橋宏樹, 山宮輝夫, 横山 裕 : 床の性能に影響するコンクリートスラ ブおよび仕上材料の仕様と施工に関する基礎的検討, 一高分子系塗り床 抢よび張り床の場合一, 日本建築学会大会学術講演梗概集, 材料施工, pp. 861-862, 2019.7

2) Takamasa MIKAMI, Eiji SAKAI, Junya HIGASHIYAMA: Influence of strength properties of substrate mortar on separation resistance of epoxy resin floor coatings loaded by running caster, Scheduled to be published on Journal of Structural and Construction Engineering (Transactionsof AIJ), No. 506, pp. 15-20, 1998. 4

三上貴正, 坂井映二, 東山純也 : キャスター走行荷重を受けるエポキシ 樹脂塗り床の耐剥離性に及ぼす下地モルタルの強度性状の影響に関する 考察, 日本建築学会構造系論文集, 第506号, pp. 15-20, 1998.4

3) Eiji SAKAI, Takamasa MIKAMI: Influence of rolling loads by casters on separation resistance of substrate concrete and synthetic resin floor coatings, Scheduled to be published on Journal of Structural and Construction Engineering (Transactionsof AIJ), No. 538, pp. 1-6, 2000. 12

坂井映二, 三上貴正 : 下地コンクリートと合成樹脂塗り床材の耐剥離性 に及ぼすキャスターの走行荷重の影響, 日本建築学会構造系論文集, 第 538号, pp. 1-6, 2000.12

4) Yutaka YOKOYAMA, Hitoshi MATSUSHITA, Takeshi YOKOI: Experimental investigation about slab surface strength and durability of resin floor coatings against rolling-load and thermal-shock, Scheduled to be published on Journal of Structural and Construction Engineering (Transactionsof AIJ), Vol. 75, No. 647, pp. 41-47, 2010. 1

横山 裕, 松下仁士, 横井 健: 塗り床のキャスター走行および熱衝撃 に対する耐久性とコンクリート床下地の表面強度に関する実験的研究, 日本建築学会構造系論文集, 第75巻, 第647号, pp. 41-47, 2010.1

5) Japanese Standards Association: JIS A 1450 Test methods for raised access floor, 2015. 7

日本規格協会：JIS A 1450：2015 フリーアクセスフロア試験方法, 2015. 7改訂

6) Japanese Standards Association: JIS A 5536 Adhesives for resilient, textile and laminate floor coverings, 2015. 6

日本規格協会：JIS A 5536:2015 床仕上げ材用接着剂, 2015.6改訂

7) Yutaka YOKOYAMA, Takeshi YOKOI: Concept of quality index on surface layer of concrete groundwork, Journal of Structural and Construction Engineering (Transactions of AIJ), No. 580, pp. 15-22, 2004. 6

横山 裕, 横井 健: コンクリート床下地の表層部品質に関する指標の あり方, 日本建築会構造系論文集, 第580号, pp. 15-22, 2004.6

8) Hidenori ONO, Yutaka YOKOYAMA, Susumu NAGAHASHI, Shigeo KAJIURA, Takeshi YOKOI, Noboru YUASA, Naoto HASHI, Kazuo KUDO: Proposal of rapid measurement and evaluation method on quality of surface layer of concrete ground work, AIJ Journal of Technology and Design, No. 18, pp. 11-16, 2003. 12

小野英哲, 横山 裕, 永橋 進, 梶浦茂男, 横井 健, 湯浅 昇, 端 直人, 小俣一夫 : コンクリート床下地表層部の諸品質の簡易測定, 評価 方法の提案, 日本建築学会技術報告集, 第18号, pp. 11-16, 2003. 12

9) Japan Research Conference of Floor Construction Technology: Method for measurement of the quality of the concrete slab surface grade, 2014. 8 日本床施工技術研究協議会 : コンクリート床下地表層部の諸品質の測定 方法, グレード, 2003.12制定, 2014.8改訂

10) Japan Floor Coating Industry Association: Coating floor handbook, 2012. 3 日本塗り床工業会 : 塗り床ハンドブック (平成24年版), 2012.3改訂

11) Hiroshi KAMATANI, Yasuyoshi TSUCHIDA, Yoshihiro ONODDERA Tsutomu ASAMI, Takashi MOCHIZUKI, Yasuo MITANI Hiroyasu SEKIGUCHI: Study on simple measurement method of floor surface hardness, Part 1 examination of measurement method, Summaries of Technical Papers of Annual Meeting, Japan Society For Finishing Technology, pp. 135-138, 1995. 9 鎌谷弘志, 土田恭義, 小野寺善弘, 浅見 勉, 望月 堯, 三谷保雄, 関 
口博康：床下地表面硬さの簡易測定方法に関する研究, その1 測定方 法の検討, 日本建築仕上学会大会学術講演会研究発表論文集, pp. 135138, 1995. 9

12) Tsutomu ASAMI, Yasuyoshi TSUCHIDA, Yoshihiro ONODDERA, Hiroyasu SEKIGUCHI, Hiroshi KAMATANI, Munekazu ARAKAWA, Takashi MOCHIZUKI: Study on simple measurement method of floor surface hardness, Part 2 examination of surface hardness by scratching force, Summaries of Technical Papers of Annual Meeting, Japan Society For Finishing Technology, pp. 181-184, 1996. 9

浅見 勉, 土田恭義, 小野寺善弘, 関口博康, 鎌谷弘志, 荒川宗和, 望 月 堯：床下地表面硬さの簡易測定方法に関する研究, その2 引つ掻 き力による表面硬さの検討, 日本建築仕上学会大会学術講演会研究発表 論文集，pp. 181-184，1996.9

13) Yasuyoshi TSUCHIDA, Yoshihiro ONODDERA, Tsutomu ASAMI, Munekazu ARAKAWA, Hiroshi KAMATANI, Hiroyasu SEKIGUCHI, Takashi MOCHIZUKI: Study on simple measurement method of floor surface hardness, Part 3 examination of scratch hardness tester, Summaries of Technical Papers of Annual Meeting, Japan Society For Finishing Technology, pp. 9-12, 1997. 10 土田恭義, 小野寺善弘, 浅見 勉, 荒川宗和, 鎌谷弘志, 関口博康, 望 月 堯：床下地表面硬さの簡易測定方法に関する研究，その3 引掻き 硬さ測定器の検討, 日本建築仕上学会大会学術講演会研究発表論文集, pp. 9-12, 1997. 10

14) Noboru YUASA, Yoshio KASAI, Isamu MATSUI, Yoshio HENMI, Hirokazu SATO: Evalution method for moisture condittion in concrete by using a humidity test paper pasted on concrete, Japan society for finishing technology, Vol. 5, No. 1, pp. 1-6, 1997. 10

湯浅 昇, 笠井芳夫, 松井 勇, 逸見義男, 佐藤弘和：乾燥度試験紙に よるコンクリートの水分状態の評価, 日本建築仕上学会論文報告集, Vol. 5, No. 1, pp. 1-6, 1997. 10

15) Yutaro FUJII, Takeshi YOKOI, Shintaro FUKUDA, Yutaka YOKOYAMA: Relationship between joint tenting of resilient floor covering and moisture vapor emission of concrete slab, Scheduled to be published on Journal of Structural and Construction Engineering (Transactionsof AIJ), Vol. 85, No. 767, pp. 11-18, 2020. 1

藤井佑太朗，横井 健，福田眞太郎，横山 裕：高分子系張り床材の突 き上げとコンクリート床下地の放出水分量の関係, 日本建築学会構造系 論文集，第85巻，第767号，pp. 11-18, 2020.1

16) Japanese Standards Association: JIS B 0601 Geometrical Product Specifications (GPS)-Surface texture: Profile method-Terms, definitions and surface texture parameters, 2013. 1

日本規格協会：JIS B 0601：2013 製品の幾何特性仕様 (GPS) 表面性 状 : 輪郭曲線方式用語, 定義及び表面性状パラメータ, 2013. 1 改訂

17) Takuma HAYASHI, Yutaro FUJII, Shintaro FUKUDA, Takeshi YOKOI, Yutaka YOKYAMA: Fundamental Study on Test Method of Wrinkle Durability of Floor Covering Part 1 Outline of Experiment and Result, Summaries of Technical Papers of Annual Meeting, Architectural Institute of Japan, Materials and Construction, pp. 1055-1056, 2018. 7

林 拓真, 藤井佑太朗, 福田眞太郎, 横井 健, 横山 裕 : 張り床の而 ふくれ性の試験方法に関する基礎的研究, その1 実験概要および実験 結果, 日本建築学会大会学術講演梗概集, 材料施工, pp. 1055-1056, 2018.7 


\title{
RELATIONSHIP BETWEEN DURABILITY AGAINST DYNAMIC LOAD OF RESIN FLOOR COATING AND SURFACE LAYER QUALITY OF SLAB CONCRETE
}

\author{
Yutaro FUJII ${ }^{* 1}$, Hiroki TAKAYAMA*2, Shintaro FUKUDA*3 \\ and Yutaka YOKOYAMA*4
}

\footnotetext{
${ }^{* 1}$ Researcher, Dept. of Architecture and Building Eng., School of Environment and Society, Tokyo Institute of Technology, Dr.Eng. ${ }^{* 2}$ Dept. of Architecture and Building Eng., School of Environment and Society, Tokyo Institute of Technology, M.Eng.

${ }^{*}$ Assist. Prof., Dept. of Architecture and Building Eng., School of Environment and Society, Tokyo Institute of Technology, Dr.Eng.

${ }^{* 4}$ Prof., Dept. of Architecture and Building Eng., School of Environment and Society, Tokyo Institute of Technology, Dr.Eng.
}

Resin floor coating is used for the floors such as logistics facilities and production facilities. Those floors could be subjected to great complicated load by guided vehicles. Due to the load, the cases are reported that the problems with the floors occur. It is expected that durability against dynamic load of Resin floor coating is strongly affected by surface layer quality. Therefore, it is very important to secure surface layer quality. However, there are few cases that the relationship between durability against dynamic load of Resin floor coating and surface layer quality is considered. So, there is a lack of knowledge to avoid the problems in advance.

Thus, in this study, the relationship between durability against dynamic load of Resin floor coating and surface layer quality is considered. The targeted dynamic load is the load applied when the casters of such as guided vehicles are carve. In addition, the effects of polisher and the process for finishing work and curing among the process for constructing slab are considered.

Some various Concrete specimens are prepared. (Reference Fig. 1) The preparing conditions are showed in Table 1, 2. Especially, by varying finishing work conditions like Table 3, the specimens with various surface layer qualities are prepared. The concrete specimens are measured three kinds of surface layer quality. Those are surface intensity, moisture vapor emission, surface roughness. Table 4 shows the grades of surface intensity. Also, measurement of Tensile adhesive strength of slab and Resin floor coating was done.

Twist load tester developed in this study was used for the durability against dynamic load test. This tester can reproduce the load applied when the casters of such as guided vehicles are carve. In order to reproduce real load, $5000 \mathrm{~N}$ and $10000 \mathrm{~N}$ load were chosen in the test. (Reference Fig. 2, Photo 1)

The results are as follows: First, Fig. 3 shows the measurement results of surface intensity, moisture vapor emission. The result that the more finishing work conditions are improved, the more surface intensity increase, and the more moisture vapor emission decrease was obtained. It is also proved that surface intensity and moisture vapor emission have good correspondence with each other. (Reference Fig. 4)

Secondly, the relationship of surface intensity between before and after polish is considered. The result shows surface intensity of polished specimens gets larger than before polish. (Reference Fig. 5)

Finally, the relationship between surface layer quality and durability against dynamic is considered. As a result, it is proved that in addition to preparation of slab by the process shown in this study, securement of appropriate surface intensity could decrease the possibility of primary problems. (Reference Fig. 9, 10) 